\title{
PENINGKATAN KEMAMPUAN PEMECAHAN MASALAH DAN SELF ESTEEM SISWA MELALUI PEMBELAJARAN HUMANISTIK BERBASIS PENDIDIKAN MATEMATIKA REALISTIK
}

\author{
Lia Rista ${ }^{1}$, Cut Yuniza Eviyanti ${ }^{2}$, Andriani $^{3}$ \\ ${ }^{1,2,3}$ Pendidikan Matematika, STKIP Bumi Persada, Lhokseumawe, Indonesia \\ leeyarista@gmail.com
}

\begin{abstract}
Problem solving is part of the mathematics curriculum which is very important in today's education world. Because in the learning process and its solution, it is possible for students to gain experience using the knowledge and skills they already have to apply them to solving problems that are not routine in nature. In solving these problems, teachers also have a very important role. The teacher must know that the child has sufficient mental development and has sufficient knowledge in solving daily problems. In this case, an increase in mathematical problem-solving abilities is also accompanied by psychology. Psychology in this case is a personality who always has self-confidence and thinks positively. One of the personalities that students must have is self-esteem. The general objective of this study was to determine the extent to which students' mathematical problem solving abilities and self-esteem through humanistic learning based on Realistic Mathematics Education (PMR). This type of research is an experiment with a quantitative approach. Meanwhile, the self-esteem assessment is in the form of a questionnaire. Based on the results of the study, it can be concluded that the increase in problem-solving and self-esteem abilities of students who get PMR-based humanistic learning is better than students who get conventional learning.
\end{abstract}

Keywords: Humanistic Learning based on RME, Problem Solving, Self Esteem

\begin{abstract}
ABSTRAK
Pemecahan masalah merupakan bagian dari kurikulum matematika yang sangat penting dalam dunia pendidikan saat ini. Karena dalam proses pembelajaran maupun penyelesaiannya, siswa dimungkinkan memperoleh pengalaman menggunakan pengetahuan serta keterampilan yang sudah dimiliki untuk diterapkan pada pemecahan masalah yang bersifat tidak rutin. Dalam menyelesaikan masalah tersebut, guru juga memiliki peran yang sangat penting. guru harus mengetahui bahwa anak perkembangan mentalnya telah cukup dan telah memiliki cukup pengetahuan dalam menyelesaian persoalan sehari-hari. Dalam hal ini, terjadinya peningkatan kemampuan pemecahan masalah matematika juga dibarengi dengan psikologi. Psikologi dalam hal ini adalah adanya kepribadian yang selalu memiliki rasa percaya diri dan berpikir positif. Salah satu kepribadian yang harus dimiliki siswa adalah self esteem. Tujuan umum dari penelitian ini adalah untuk mengetahui sejauh mana kemampuan pemecahan masalah matematis dan self esteeme siswa melalui pembelajaran humanistik berbasis Pendidikan Matematika Realistik (PMR) . Jenis penelitian adalah eksperimen dengan pendekatan kuantitatif. Sedangkan penilaian self esteem berupa angket. Berdasarkan hasil penelitian dapat disimpulkan bahwa Peningkatan kemampuan pemecahan masalah dan self esteem siswa yang memperoleh pembelajaran humanistik berbasis PMR lebihbaik daripada siswa yang memperoleh pembelajaran konvensional.
\end{abstract}

Kata Kunci: Pembelajaran Humanistik Berbasis PMR, Pemecahn Masalah, Self Esteem

\section{PENDAHULUAN}

Pemecahan masalah merupakan bagian dari kurikulum matematika yang sangat penting dalam dunia pendidikan saat ini. Karena dalam proses pembelajaran maupun penyelesaiannya, siswa dimungkinkan memperoleh pengalaman menggunakan pengetahuan serta keterampilan yang sudah dimiliki untuk diterapkan pada pemecahan masalah yang bersifat tidak rutin. Pelajaran matematika saat ini banyak sekali mengaitkan teori dengan permasalahan sehari-hari yang berada di lingkungan sekitar. Permasalahan biasanya memuat suatu yang mendorong seseorang untuk menyelesaikannya 
akan tetapi tidak secara langsung seseorang dapat menyelesaikannya. Jika suatu masalah diberikan kepada seorang anak dan anak tersebut langsung mengetahui cara menyelesaikannya dengan benar, maka soal tersebut tidak dapat dikatakan sebagai masalah. Salah satu tujuan pembelajaran matematika di sekolah (Wardani \& Purnomo, Sapon Suryo Wahyuningsih, 2010) adalah memecahkan masalah yang meliputi kemampuan memahami masalah, merancang model matematika, menyelesaikan model, dan menafsirkan solusi yang diperoleh. Untuk memperoleh kemampuan dalam pemecahan masalah, seseorang harus memiliki banyak pengalaman dalam memecahkan berbagai masalah.

Berdasarkan wawancara dengan beberapa orang guru matematika SMA sekitar Lhokseumawe, diperoleh informasi bahwa siswa sebenarnya terbiasa dengan soal-soal pemecahan masalah akan tetapi soal yang diberikan bersifat monoton sehingga tidak ada perubahan dalam hal kemampuan kognitif siswa dan siswa belum mampu berpikir secara mandiri dalam memecahkan masalah. Sehingga mereka tidak percaya diri dalam menyelesaikan soal yang diberikan.Kemampuan siswa dalam memecahkan masalah belum berkembang secara optimal.

Dalam menyelesaikan masalah tersebut, guru juga memiliki peran yang sangat penting. guru harus mengetahui bahwa anak perkembangan mentalnya telah cukup dan telah memiliki cukup pengetahuan prasyarat untuk menyelesaikan soal tersebut, agar siswa tidak buntu berpikir karena masalah lain (bahasa dan matematika sukar). Dalam hal ini, terjadinya peningkatan kemampuan pemecahan masalah matematika juga dibarengi dengan psikologi. Psikologi dalam hal ini adalah adanya kepribadian yang selalu memiliki rasa percaya diri dan berpikir positif. Salah satu kepribadian yang harus dimiliki siswa adalah self esteem, yaitu suatu perasaan dimana seseorang merasa bahwa dirinya berharga dan merasa bangga terhadap dirinya atau dapat dikatakan seberapa besar kita menyukai diri kita sendiri (Mruk, 1995). Self Esteem yang tinggi itulah yang akan mendorong diri kita, hubungan kita dengan orang lain, dan tingkat kepercayaan diri kita.

Salah satu alternatif untuk meningkatkan kemampuan pemecahan masalah dan self esteem siswa tersebut adalah dengan menerapkan pembelajaran matematika humanistik berbasis PMR (pendidikan matematika realistik). (Hendriana, 2012) Membuat matematika yang humanis dalam pembelajarannya merupakan modal awal untuk memberikan stimulus sejak dini kepada siswa sehingga tanggapan negatif terhadap matematika berkurang. Dengan menyenangi matematika, belajar matematika menjadi sebuah kebanggaan bagi siswa sehingga diharapkan kebiasaan berpikir kreatif menjadi terlatih. Susilo (Rista, 2019) Pelajaran matematika secara humanistik berarti menempatkan matematika sebagai bagian dari kehidupan nyata manusia. Proses pembelajarannya juga menempatkan pelajar bukan sebagai obyek, melainkan subyek yang bebas menemukan pemahaman berdasarkan pengalamannya sehari-hari. Dalam kaitan ini ada beberapa pendekatan pembelajaran yang diyakini sejalan dengan pembelajaran yang menekankan sifat humanistik antara lain Pendidikan Matematika Realistik (PMR) yaitu pembelajaran matematika sekolah yang dilaksanakan dengan menempatkan realitas dan pengalaman siswa sebagai titik awal pembelajaran. 
Peningkatan Kemampuan Pemecahan Masalah dan Self Esteem Siswa Melalui Pembelajaran Humanistik Berbasis

Berdasarkan yang diuraikan diatas peneliti meyakini bahwa pembelajaran matematika Humanistik berbasis Pendidikan Matematika Realistik (PMR) sangat tepat digunakan untuk meningkatkan kemampuan pemecahan masalah dan self esteem siswa. Sehingga peneliti bertujuan ingin mengembangkan kembali atau meneliti tentang: Apakah terdapat perbedaan yang signifikan peningkatan kemampuan pemecahan matematika siswa dan self esteem siswa yang memperoleh pembelajaran humanistik berbasis PMR dengan siswa yang memperoleh pembelajaran konvensional ditinjau dari:(a) secara keseluruhan, (b) berdasarkan level siswa (tinggi, sedang, rendah)?

\section{METODE}

Penelitian ini berkenaan tentang meningkatkan kemampuan pemecahan masalah matematis dan self esteem siswa melalui pembelajaran matematika humanistik berbasis PMR (Pendidikan Matematika Realistik). Metode penelitian yang dilakukan dalam penelitian ini adalah penelitian eksperimen murni (true experimental) dengan rancangan random atau disebut juga randomized pretest - postest control group design. Gambaran tentang desain ini dapat dilihat pada gambar dibawah ini. Desain penelitian ini berbentuk:

Kelas eksperimen

Kelas kontrol

\begin{tabular}{lll}
$\mathrm{O}$ & $\mathrm{X}$ & $\mathrm{O}$ \\
\hline $\mathrm{O}$ & $\mathrm{C}$ & $\mathrm{O}$
\end{tabular}

Keterangan :

$\mathrm{O}:$ Pretest dan postest

$X$ : Perlakuan pembelajaran humanistik berbasis PMR.

C : Pembelajaran matematika tanpa perlakuan humanistik berbasis PMR.

Selanjutnya, untuk mengetahui secara lebih mendalam pengaruh pembelajaran humanistik berbasis PMR terhadap kemampuan pemecahan masalah matematis dan self esteem siswa pada kelas eksperimen serta perbedaannya dengan kelas kontrol yang diterapkan pembelajaran konvensional, maka perhatikan tabel kerterkaitan antara variabel bebas, variabel terikat dan kontol yang disajikan dalam tabel Weiner.

\section{Populasi dan Sampel}

Penelitian telah dilaksanakan secara daring menggunakan Via Zoom di kelas X SMA Negeri 1 Lhokseumawe yang terletak di Kecamatan Banda Sakti kota Lhokseumawe. Sebelum melakukan penelitian, peneliti telah melakukan wawancara terutama kepada pihak Kepala Sekola dan Guru Bidang studi, untuk menanyakan waktu yang tepat melaksanakan proses pembelajaran secara daring, terlihat disaat pandemi saat ini waktu dan ruang yang diberikan sangat terbatas.

\section{Tahap Pengolahan Data}

Data yang diperoleh melalui pretest dan postes dianalisis menggunakan analisis statistik dan melakukan penarikan kesimpulan terhadap hasil analisis data dan kemudian penulisan laporan. 
Penelitian ini terdapat dua pengukuran instrumen yaitu kemampuan pemecahan masalah matematis dan self esteem siswa.

\section{Instrumen Kemampuan Pemecahan Masalah dan Self Esteem}

Instrumen yang digunakan sebagai pengukuran kemampuan pemecahan matematis dengan menggunakan soal uraian dan angket. Indikator kemampuan pemecahan masalah bedasarkan Indikator pemecahan masalah yang termuat dalam pada (Scheffer \& Markus, 2016) peraturan Menteri Pendidikan Nomor 22 Tahun 2006, antara lain: memiliki kemampuan memahami masalah, merancang model matematika, menyelesaikan model, dan menafsirkan solusi yang diperoleh. Utari (2010) menyatakan bahwa tujuannya adalah siswa mampu mengidentifikasi unsur yang diketahui, ditanyakan, dan kecukupan unsur; membuat model matematika; menerapkan strategi menyelesaikan masalah dalam/ di luar matematika, menjelaskan/ menginterpretasikan hasil; menyelesaikan model matematika dan masalah; serta menggunakan matematika secara bermakna.

Selanjutnya instrumen self Esteem berupa angket berdasarkan indikator self esteem tinggi dan rendah (Larasati et al., 2012)

\section{Tabel 1.}

Karakteristik Self Esteem Tinggi dan Rendah

\begin{tabular}{|l|l|}
\hline Self esstem tinggi & Self esteem Rendah \\
\hline Merasa puas terhadap dirinya & Merasa tidak puas dengan dirinya \\
\hline Menanggapi kritik dan pujian sebagai masukan & $\begin{array}{l}\text { Sulit menerima pujian akan tetapi terganggua } \\
\text { dengan kritikan }\end{array}$ \\
\hline $\begin{array}{l}\text { Dapat menerima kegagalan dan bangkit dari } \\
\text { kegagalan }\end{array}$ & Sulit menerima kegagalan dan kecewa \\
\hline Memandang hidup secara positif & $\begin{array}{l}\text { Memandang hidup dan berbagai kejadian } \\
\text { sebagai hal negatif }\end{array}$ \\
\hline $\begin{array}{l}\text { Mudah untuk berinteraksi, berhubungandekat } \\
\text { dengan orang lain }\end{array}$ & $\begin{array}{l}\text { Sulit untuk berinteraksi, berhubungan dengan } \\
\text { orang lain }\end{array}$ \\
\hline Optimis & Pesimis \\
\hline $\begin{array}{l}\text { Berpikir konstruktif (dapat mendorong diri } \\
\text { sendiri) }\end{array}$ & $\begin{array}{l}\text { Berpikir yang tidak membangun (merasa tidak } \\
\text { dapat membantu diri sendiri }\end{array}$ \\
\hline
\end{tabular}

\section{Teknik Analisis Data}

Pada tahap ini peneliti melaksanakan analisis terhadap seperangkat data yang telah diperoleh dari nilai KAM, kemampuan pemecahan masalah (pretes dan postes) dan skala self esteem (pretes dan postes) untuk di analisis secara kuantitatif. Pengolahan skor pretest dan postest untuk menentukan gain ternormalisasi (normalized gain). Untuk menghitung gain ternormalisasi digunakan rumus yang dikemukakan oleh (Hake, 2007):

Setelah diperoleh nilai gain ternormalisasi, maka perlu dilakukan uji normalitas dan uji homogenitas kemampuan pemecahan masalah matematis dan self esteem siswa. Uji homogenitas varians antara kelompok eksperimen dan kontrol dimaksudkan untuk mengetahui keadaan kedua 
Peningkatan Kemampuan Pemecahan Masalah dan Self Esteem Siswa Melalui Pembelajaran Humanistik Berbasis

kelompok berasal dari populasi yang memiliki varian sama atau berbeda. Pengujian homogenitas ini menggunakan uji varians dua buah peubah bebas. Pengujian hipotesis statistik dalam penelitian ini adalah Anava dua jalur menggunakan SPSS versi 20.

\section{HASIL}

Penelitian ini bertujuan untuk menganalisis kemampuan pemecahan masalah dan self esstem siswa. Proses pembelajaran dilakukan cara dari terhadap dua kelas yaitu kelas eksperimen dan kelan konvensional. Sedikit kendala saat proses pembelajaran secara daring dikarenakan sering terganggu dengan konektivitas selama pembelajaran. Apalagi hasil yang didapat selama dilaangan bahwasannya siswa merasa kesulitan belajar secara daring, karena kodisi covid saat ini. Sebagian siswa merasa terkadang pembelajaran sanga sulit diterima dan sudah dalam memahami pembelajaran. Akan tetapi peneliti melakukan proses pembelajaran yang berbeda dengan menggunakan pembelajaran humanistik dengan dorongan positif terhadap psikologi siswa. Siswa merasa dihargai dan termotivasi dengan proses pembelajaran Humanistik berbasis PMR dan Self Esteem siswa.

Melalui proses tersebut telah menghasilkan data dan selanjutnya melakukan tahapa pengolahan data dengan menggunakan bantuan SPSS 20.0 for Windows dan Microsoft Office Excel 2010.

\section{Data Deskriptif Hasil Penelitian Pemecahan Masalah}

Berikut ini data skor pretes, postes dan gain ternormalisasi (N-Gain) dalam bentuk tabel.

\section{Tabel 2.}

Data Deskriptif Pemecahan Masalah Siswa

\begin{tabular}{|c|c|c|c|c|c|c|c|c|c|c|c|}
\hline \multirow{2}{*}{$\begin{array}{l}\text { Kemampuan } \\
\text { Matematik }\end{array}$} & \multirow{2}{*}{ Tes } & \multicolumn{5}{|c|}{ Kelas Eksperimen } & \multicolumn{5}{|c|}{ Kelas Kontrol } \\
\hline & & $\mathbf{N}$ & Xmax & Xmin & $(\bar{x})$ & $S$ & $\mathbf{N}$ & Xmaks & Xmin & $(\bar{x})$ & $S$ \\
\hline Pemecahan & Pretes & 24 & 75 & 25 & 35,96 & 15.606 & 24 & 65 & 20 & 35.12 & 12.60 \\
\hline \multirow[t]{2}{*}{ Masalah } & Postes & 24 & 90 & 70 & 85,12 & 13.668 & 24 & 50 & 85 & 75.7 & 11.90 \\
\hline & $\overline{\text { Gain }}$ & 24 & & & 0.57 & 0.199 & 24 & & & 0.50 & 0.50 \\
\hline
\end{tabular}

Dari hasil data pada tabel di atas tersebut membuktikan bahwa terdapat peningkatan yang signifikan kelas eksperimen dibandingkan kelas kontrol.

\section{Analisis Peningkatan Pemecahan Masalah}

Sesuai dengan tujuan dilakukannya perhitungan indeks gain, yaitu untuk mengetahui peningkatan Pemecahan Masalah siswa setelah pembelajaran, maka diuji untuk melihat peningkatan serta nilai indeks gain ini diperoleh dari hasil pretes dan postes siswa pada kelas kontrol dan kelas eksperimen.

\section{Uji Normalitas Gain Pemecahan Masalah}

Hipotesis yang akan diuji adalah:

$H_{o}$ : Skor N-Gain kemampuan pemecahan masalah berdistribusi normal 
$H_{1}:$ Skor N-Gain kemampuan pemecahan masalah tidak berdistribusi normal

Untuk menguji normalitas N-Gain Pemecahan Masalah menggunakan uji KolmogorovSmirnov melalui SPSS 16.0 pada taraf signifikansi $\alpha=0,05$. Kriteria pengujian adalah tolak $H_{o}$ apabila Sig. < taraf signifikansi (Uyanto, 2009) Rangkuman perhitungan uji normalitas dapat dilihat pada tabel berikut.

\section{Tabel 3.}

Uji Normalitas Gain Pemecahan Masalah

\begin{tabular}{lllcl}
\hline Kelas & Kolmogorov-Smirnov & Sig. & Kesimpulan & Keterangan \\
\hline Eksperimen & 0,100 & 0,200 & Terima $H_{o}$ & Normal \\
\hline Kontrol & 0,165 & 0,060 & Terima $H_{o}$ & Normal \\
\hline
\end{tabular}

Tabel di atas terlihat bahwa nilai Sig. > 0,05. Artinya data gain kedua kelas untuk Pemecahan Masalah berdistribusi normal. Akan dilanjutkan uji homogenitas varians untuk kedua kelas.

\section{Uji Homogenitas Pemecahan Masalah}

Hipotesis statistik yang akan diuji adalah:

$H_{o}: \sigma_{1}^{2}=\sigma_{2}^{2}$

$H_{1}: \sigma_{1}^{2} \neq \sigma_{2}^{2}$

\section{Keterangan,}

$\sigma_{1}^{2}=$ Varians gain ternormalisasi (N-Gain) kelas eksperimen

$\sigma_{2}^{2}=$ Varians gain ternormalisasi (N-Gain) kelas kontrol

Untuk menguji homogenitas varians N-Gain menggunakan uji Levene melalui SPSS 16.0 pada taraf signifikansi $\alpha=0,05$. Kriteria pengujian adalah tolak $H_{o}$ apabila Sig. < taraf signifikansi. Untuk lebih jelas dapat dilihat pada tabel berikut.

\section{Tabel 4.}

Uji Homogenitas Varians N-Gain Pemecahan Masalah

\begin{tabular}{lllll}
\hline Kelas & Uji Levene & Sig. & Kesimpulan & Keterangan \\
\hline Eksperimen & .321 & 0.573 & Terima $H_{o}$ & Homogen \\
\hline Kontrol & .32 & &
\end{tabular}

Dari tabel 4 diperoleh bahwa pada aspek Pemecahan Masalah dengan nilai $\mathrm{F}=.321 \mathrm{dan} \mathrm{Sig}$ > 0,05 maka $H_{o}$ diterima artinya varians gain ternormalisasi Pemecahan Masalah kedua kelas homogen. Setelah diketahui bahwa data gain ternormalisasi berdistribusi normal dan memiliki varians yang homogen, langkah selanjutnya adalah menguji perbedaan peningkatan Pemecahan Masalah dengan menggunakan $\mathrm{Uji}-\mathrm{t}$.

\section{Uji Perbedaan Peningkatan Gain Ternormalisasi (N-Gain) Pemecahan Masalah}

Uji perbedaan rata-rata N-Gain Pemecahan Masalah siswa pada kedua kelas bertujuan untuk membuktikan hipotesis yang pertama. Adapun hipotesis penelitian yang diajukan adalah: 
Hipotesis 1: Terdapat perbedaan yang signifikan peningkatan kemampuan Pemecahan Masalah siswa yang memperoleh pembelajaran dengan humanistik berbasis PMR dibandingkan siswa yang memperoleh pembelajaran secara konvensional

$\mathrm{H}_{0}: \mu_{g e}=\mu_{g k}$

$\mathrm{H}_{1}: \mu_{g e}>\mu_{g k}$

Keterangan:

$\mu_{g e}=$ rata-rata gain ternomalisasi Pemecahan Masalah kelas eksperimens

$\mu_{g k}=$ rata-rata gain ternomalisasi Pemecahan Masalah kelas kontrol

Perhitungan menggunakan SPSS 16.0 pada taraf signifikansi $\alpha=0,05$. Kriteria pengujian adalah tolak $H_{o}$ apabila Sig.(1-tailed) < taraf signifikansi $\alpha=0,05$ (Uyanto, 2009) Perhitungan selengkapnya dapat dilihat pada lampiran, rangkuman hasil perhitungan dari SPSS dapat dilihat pada tabel berikut.

\section{Tabel 5.}

Uji Perbedaan Rata-rata N-Gain Pemecahan Masalah

\begin{tabular}{lllll}
\hline Kelas & t hitung & Sig. (2-tailed) & Sig. (1-tailed) & Kesimpulan \\
\hline Eksperimen & 2.189 & 0.040 & 0.02 & Tolak $\mathrm{H}_{0}$ \\
\hline Kontrol & 2.19 &
\end{tabular}

Dari tabel atas dapat dilihat bahwa rata-rata gain ternormalisasi Pemecahan Masalah kelas eksperimen lebih baik daripada rata-rata gain ternormalisasi kelas kontrol. Sehingga dapat disimpulkan Terdapat perbedaan yang signifikan peningkatan kemampuan Pemecahan Masalah siswa yang memperoleh pembelajaran dengan humanistik berbasis PMR dibandingkan siswa yang memperoleh pembelajaran secara konvensional.

\section{Analisis Peningkatan Self Esteem}

Analisis peningkatan self esteem siswa pada kedua kelas yaitu kelas eksperimen dan kelas kontrol. Untuk menunjukkan bahwa peningkatan self esteem siswa kelas eksperimen lebih baik dari kelas kotrol diperlukan uji statistik lanjut.

Pengujian terhadap peningkatan self esteem siswa pada kelas eksperimen dan kelas kontrol dilakukan dengan menganalisis data gain ternormalisasi (N-gain). Rataan gain ternormalisasi merupakan gambaran peningkatan setelah mengikuti pembelajaran, baik yang mengikuti pembelajaran dengan humanistik berbasis PMR (kelas eksperimen) maupun yang mengikuti pembelajaran dengan pendekatan konvensional (kelas kontrol). Berikut ini disajikan analisis statistik deskriptif data N-gain secara keseluruhan antara kelas eksperimen dan kelas kontrol. 


\section{Uji Normalitas Gain Self Esteem}

Sebelum melakukan uji statistik, hal yang perlu dilakukan terlebih dahulu adalah menguji normalitas dan homogenitas varians terhadap data kedua kelompok siswa yaitu siswa kelas eksperimen dan siswa kelas kontrol. Untuk menguji normalitas gain pada penelitian ini digunakan uji Kolmogorov-smirnov dengan perumusan hipotesis pengujian normalitas sebagai berikut:

$\mathrm{H}_{0} \quad$ : Sampel berasal dari populasi yang berdistribusi normal

$\mathrm{H}_{1}$ : Sampel berasal dari populasi yang tidak berdistribusi normal

Dengan menggunakan taraf signifikasi $\alpha=0,05$ maka kriteria pengujiannya adalah sebagai berikut:

Terima $\mathrm{H}_{0}$ jika nilai sig. $\geq \alpha$

Tolak $\mathrm{H}_{0}$ jika nilai sig. $<\alpha$

Hasil dari analisis normalitas uji kolmogorov-smirnov untuk data $\mathrm{N}$ - gain kelas eksperimen dan kelas kontrol disajikan dalam tabel berikut:

\section{Tabel 6.}

Uji Normalitas Data N-Gain Self Esteem Siswa

\begin{tabular}{llll}
\hline \multirow{2}{*}{ Kemandirian Belajar } & \multicolumn{3}{l}{ Kolmogorov-Smirnov $^{\text {a }}$} \\
\cline { 2 - 4 } & Statistic & Df & Sig. \\
\hline N- gain kelas eksperimen & .152 & 26 & $.124^{*}$ \\
\hline N- gain kelas control & .122 & 26 & .200 \\
\hline
\end{tabular}

Berdasarkan Tabel di atas terlihat bahwa data N-gain kemandirian belajar siswa kelas eksperimen dan kelas kontrol memiliki nilai sig. $>\alpha=0,05$, kelas eksperimen memiliki nilai signifkansi 0,124 dan kelas kontrol 0,200 . Hal ini berarti $\mathrm{H}_{0}$ diterima atau dengan kata lain data $\mathrm{N}$ gain kelas eksperimen dan kelas kontrol berasal dari populasi yang berdistribusi normal.

\section{Uji Homogenitas Gain Self Esteem Siswa}

Berdasarkan hasil uji normalitas sebelumnya diketahui bahwa data N-gain Self Esstem kedua kelas berdistribusi normal sehingga dapat dilakukan uji kecocokan (homogenitas) varians. Uji homogenitas varians yang dilakukan pada penelitian ini adalah Uji Levene Statistic dengan perumusan hiptesis pengujian sebagai berikut:

$\mathrm{H}_{0} \quad$ : Kedua kelas memiliki varians yang homogen

$\mathrm{H}_{1}$ : Kedua kelas memiliki varians yang tidak homogen

Dengan menggunakan taraf signifikasi $\alpha=0,05$ maka kriteria pengujiannya adalah sebagai berikut:

1. Terima $\mathrm{H}_{0}$ jika nilai sig. $\geq \alpha$

2. Tolak $\mathrm{H}_{0}$ jika nilai sig. $<\alpha$ 
Peningkatan Kemampuan Pemecahan Masalah dan Self Esteem Siswa Melalui Pembelajaran Humanistik Berbasis

Hasil dari analisis homogenitas varians Uji Levene Statistic untuk data N-gain kelas eksperimen dan kelas kontrol disajikan dalam tabel berikut:

\section{Tabel 7.}

Uji Homogenitas Varians N-Gain Self Esstem

\begin{tabular}{llll}
\hline Levene Statistic & df1 & df2 & Sig. \\
\hline .833 & 1 & 50 & .366 \\
\hline
\end{tabular}

Berdasarkan Tabel di atas dan kriteria pengujian di atas terlihat bahwa nilai sig. $\mathrm{N}$-gain > 0,05. Hal ini berarti $\mathrm{H}_{0}$ diterima atau dengan kata lain $\mathrm{N}$-gain kedua kelas memiliki varians yang homogen.

\section{Uji Perbedaan Peningkatan Self Esstem Siswa}

Berdasarkan hasil pengujian sebelumnya, diketahui bahwa data N-gain Self Esstem kedua kelas berdistribusi normal dan variansinya homogen sehingga statistik yang digunakan untuk menguji hipotesis penelitian ini adalah uji parametrik yaitu uji-t. Analisis ini dilakukan untuk mengetahui pengaruh dari pemberian dua perlakuan yang berbeda pada kedua kelas yang menjadi sampel penelitian. Hasil perhitungan uji t dilakukan dengan bantuan SPSS versi 16 dengan taraf signifikansi $5 \%$.

Hipotesis dalam uji perbedaan rata-rata data $\mathrm{N}$-gain pada penelitian ini adalah sebagai berikut:

$\mathrm{Ha}$ : Terdapat perbedaan yang signifikan peningkatan Self Esstem siswa yang memperoleh pembelajaran dengan pembelajaran Humanistik berbasis PMR dibandingkan siswa yang memperoleh pembelajaran secara konvensional.

$\mathrm{H}_{0}$ : tidak terdapat perbedaan yang signifikan peningkatan Self Esstem siswa yang memperoleh pembelajaran dengan pembelajaran humanistik PMR dibandingkan siswa yang memperoleh pembelajaran secara konvensional.

Dengan menggunakan taraf signifikasi $\alpha=0,05$ maka kriteria pengujiannya adalah sebagai berikut:

1. Terima $\mathrm{H}_{0}$ jika nilai sig. $\geq \alpha$

2. Tolak $\mathrm{H}_{0}$ jika nilai sig. $<\alpha$

Hipotesis statistik diajukan sebagai berikut:

$\mathrm{H}_{0}: \mu_{g e}=\mu_{g k}$

$\mathrm{H}_{1}: \mu_{g e}>\mu_{g k}$

Keterangan:

$\mu_{g e}=$ rata-rata gain ternormalisasi Self Esstem siswa kelas

eksperimens 
$\mu_{g k}=$ rata-rata gain ternormalisasi Self Esstem siswa kelas kontrol

Perhitungan selengkapnya dapat dilihat pada lampiran, rangkuman hasil perhitungan dari SPSS dapat dilihat pada tabel berikut.

\section{Tabel 8.}

Uji Perbedaan Rata-rata N-Gain Self Esstem

\begin{tabular}{llll}
\hline Kelas & T & Sig. (2-tailed) & Sig. (1-tailed) \\
\hline N-gain & 4.570 & .000 & .000 \\
\hline
\end{tabular}

Dari Tabel di atas dapat dilihat bahwa pada gain Self Esstem siswa dengan nilai $\mathrm{t}=4.570$ dan Sig. (2-tailed) = 0,00. Karena menurut (Uyanto, 2009) melakukan uji hipotesis satu sisi (1-tailed) maka nilai Sig. (2-tailed) harus dibagi dua menjadi nilai Sig. (1-tailed). Karena nilai Sig. (1-tailed) < taraf Signifikansi $(\alpha=0,05)$, maka $H_{o}$ ditolak. Sehingga dapat disimpulkan bahwa rata-rata gain ternormalisasi Self Esstem siswa kelas eksperimen lebih baik dari kelas kontrol. Dengan demikian dapat disimpulkan bahwa Terdapat perbedaan yang signifikan peningkatan Self Esstem siswa yang memperoleh pembelajaran dengan pembelajaran humanistik berbasis PMR dibandingkan siswa yang memperoleh pembelajaran secara konvensional.

\section{KESIMPULAN}

Berdasarkan hasil analisis data penelitian tentang kemampuan pemecahan masalah dan self-esteem siswa yang diajar melalui pembelajaran humanistik berbasis PMR dan pembelajaran biasa, maka diperoleh beberapa kesimpulan:

1. Pada gain Pemecahan masalah matematis dengan nilai $\mathrm{t}=2.189$ dan Sig. $(1$-tailed $)=0.02$ maka $H_{O}$ ditolak. Sehingga dapat disimpulkan bahwa rata-rata gain ternormalisasi pemecahan masalah matematis siswa kelas eksperimen lebih baik dari kelas kontrol. Dengan demikian Peningkatan kemampuan pemecahan masalah siswa yang memperoleh pembelajaran humanistik berbasis PMR (kelompok eksperimen) lebihbaik daripada siswa yang memperoleh pembelajaran biasa (kelompok kontrol).

2. Pada gain Self Esstem siswa dengan nilai $t=4.570$ dan Sig. (1-tailed) $=0,00$. Karena nilai Sig. $(1$-tailed $)<$ taraf Signifikansi $(\alpha=0,05)$, maka $H_{o}$ ditolak. Sehingga dapat disimpulkan bahwa rata-rata gain ternormalisasi Self Esstem siswa kelas eksperimen lebih baik dari kelas kontrol. Dengan demikian peningkatan self esteem siswa yang memperoleh pembelajaran humanistik berbasis PMR (kelompok eksperimen) lebih tinggi daripada siswa yang memperoleh pembelajaran biasa (kelompok kontrol.

\section{DAFTAR PUSTAKA}

Hake, R. R. (2007). Design-Based Research in Physics Education: a Review. Education, March, 124. 
Peningkatan Kemampuan Pemecahan Masalah dan Self Esteem Siswa Melalui Pembelajaran Humanistik Berbasis

http://citeseerx.ist.psu.edu/viewdoc/download?doi=10.1.1.69.6409\&amp;rep=rep1\&amp;type=p df

Hendriana, H. (2012). Pembelajaran Matematika Humanis Dengan Metaphorical Thinking Untuk Meningkatkan Kepercayaan Diri Siswa. Infinity Journal, 1(1), 90. https://doi.org/10.22460/infinity.v1i1.9

Larasati, W. P., Psikologi, F., Studi, P., Profesi, P., Pendidikan, P. P., \& Indonesia, U. (2012). MENINGKATKAN SELF-ESTEEM MELALUI METODE SELF-INSTRUCTION ( Enhancing Self-esteem through Self-instruction Method ).

Mruk, C. J. (1995). Self-esteem: research, theory, and practice. In Choice Reviews Online (Vol. 32, Issue 10). https://doi.org/10.5860/choice.32-5938

Rista, L. (2019). Peningkatan Kemampuan Representasi Matematis dan Self Confidence Siswa Melalui Pembelajaran Humanistik Berbasis PMR. 03(02), 539-546. http://jurnal.unsil.ac.id/index.php/sncp/article/view/1093

Scheffer, M., \& Markus, K. (2016). PERATURAN MENTERI PENDIDIKAN DAN KEBUDAYAAN. $3345-3356$.

Uyanto. (2009). Pedoman Analisis Data dengan SPSS. Jakarta: Graha Ilmu.

Wardani, S., \& Purnomo, Sapon Suryo Wahyuningsih, E. (2010). Pembelajaran Kemampuan Penyelesaian masalah Matematika Di SD. Yogyakarta: Departemen Pendidikan Nasional. 